年次大会・抄紙セッションA

新型多層板紙用フォーマ（MH-B フォーマ）について

三菱重工業株式会社三原製作所 坂東 貴司, 藤木 恵一
開 発 課 庄司 康之
三菱重工業株式会社広島研究所 岩 田 弘

\title{
New Multi-Ply Board Former (MH-B Former)
}

\author{
T. Bando, K. Fujiki, Y. Syouji and H. Iwata \\ Mitsubishi Heavy Industries, ltd.
}

\begin{abstract}
Mitsubishi New Multi-Ply Former (MH-B Former) has been developed by utilizing the existing forming technology in the paper grade field timely consolidating the industry's trend and market needs. A combination of ACDEFLO headbox and two-fabric (felt and wire) former with compact design will give many benefits to the customer.
\end{abstract}

\section{1. まえがき}

近年，世界的なトレンドである古紙利用率の増加は， 従来からその利用率の高かった板紙分野においても， 白板紙やライナ紙の表層付け量減に伴う表面性の改善 要求や，中層に使用する古紙のリサイクル度が增すこ とによる強度及びかさの低下等大きな影響を与えるの で深刻な問題である。一方，板紙抄紙はその大きな坪 量ゆえに一層で抄くのは難しく，単体のユニットで抄 造された紙層を多数重ねて抄き合わせていく多層紙形 成法が採られる。しかしながら，従来の紙層形成法で は, 抄き合わせ部の原料飲込久性能と地合形成能力の 点で一層当りの付量に制約を受けるため，ユニット数 の多い複雑な機械構成になると同時に広い設置面積を 必要とした。これら紙品質に対する要求を満足し，安 価でしかも生産性をあげることのできる抄紙機が望ま れている。

これら市場トレンド，業界ニーズに対し，印刷用紙 用抄紙機の分野で培ってきたフォーミング技術を板紙 抄造に適用することにより，前記要求品質を洅足し， コンパクトで抄造能力の高いフォーミングコンセプト を確立した。そのフォーミングコンセプトの特徴及び テスト抄紙機，実機での検証結果に基づく本フォーマ の性能についてここに報告する。尚，本フォーマは 我々三菱重工 (MHI) が独自に開発した板紙 (Board)
用フォーマという意味で $\mathrm{MH}-\mathrm{B}$ フォーマと名付けら れた。

\section{2. フォーミング機器構成とコンセプト}

フォーミングュニット（ヘッドボックス，フォー マ）の構成を図１に示す。各フォーミングュニットは 1 枚のフェルトループの下に配置されており，各ユニ ットで形成される紙層はフェルトによって運ばれてき た湿紙と抄き合わされる次ユニットに移行するという 円網に似た抄き合わせ，湿紙移送方法を採用した。

\section{1 ヘッドボックス}

へッドボックスは，フェルトループとブレストロー ルの限られたスペースに配置出来るものとしてハイド

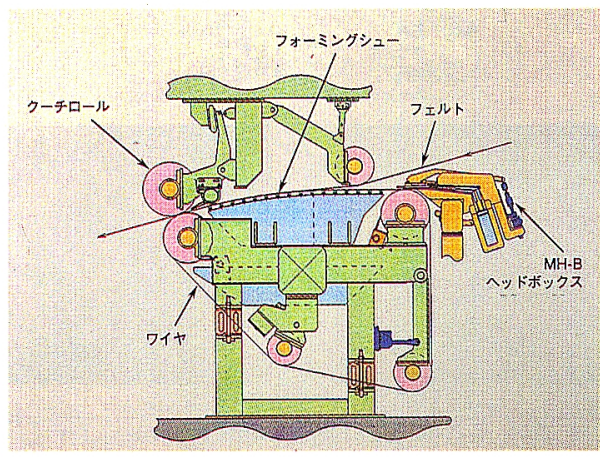

図 1 フォーミングユニット 
ロリック型を採用した。図 2 に流路断面図を示す。角 形テーパヘッダで流体圧を巾方向均一に保たれた原料 液はステップチューブの高い圧力損失により巾方向均 一に分配される。又，ステップ部での強いタービュレ ンスは大きなフロックを破壊する効果を持つ。スライ ス室は低速 (低流量), 高濃度でも分散及び整流能力 の高い加減速流路 (ACDEFLO) を採用した。巾方 向分配性能を図 3, 分散性能を図 4 に示す。何れも $120 \mathrm{~m} / \mathrm{min} ., \quad 150 \mathrm{~m} / \mathrm{min}$. とハイドローリック型ヘッ ドボックスとしては適用範囲の下限近い速度であるに もかかわらず優れた性能を示している。

\section{2 フォーマ}

フォーマパートには印刷用紙用フォーマの脱水機器 としてその性能評価の高い大きな曲率半径上に脱水ブ

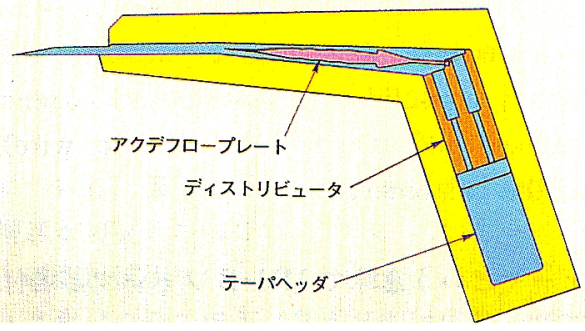

図 2 ヘッドボックスコンセプト

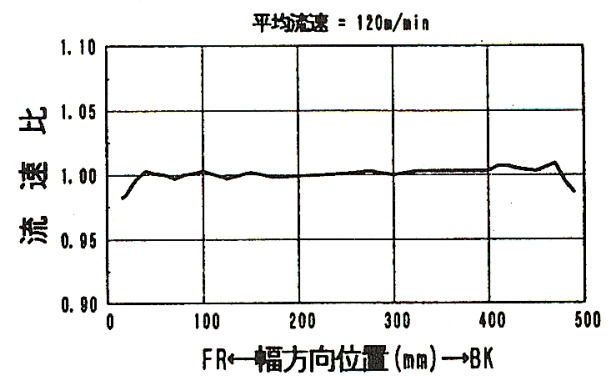

図 3 ジェット流速分布

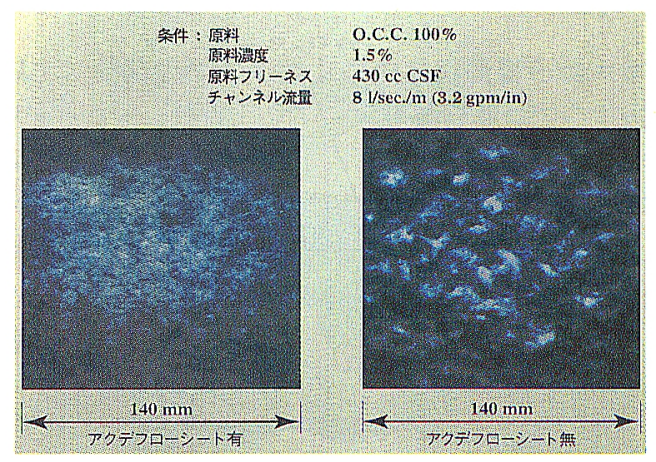

図 4 繊維分散比較
レードを配置したシューフォーミングを採用した。但 し，一方の抄き網がフェルト十湿紙で構成されて扔り， 抄き合わせ部におけるフェルト側への脱水抵抗が通常 のツインワイヤフォーミングに比べ非常に高くなって いる。このコンセプトが前記多層紙に要求される紙品 質を最適化する。すなわち, 図 5，6に示すウェット オンセミドライフォーミングとパルスフォーミングで ある。図5において，ヘッドボックスから噴出された 原料シェットはフラットなフォーミングボード上で緩 やかに初期脱水されてワイヤ側にマットを形成しなが ら抄き合わせ部（曲率部）へと進入する。この時，原 料液の上面はへッドボックスから噴出された濃度に近 い状態を保っており，前ユニットで形成された湿紙が 接触すると, 原料側から湿紙側に水が浸透し湿紙濃度 が下がる。従って，より低い濃度で抄き合わされるこ とになり，層閒強度が増す。

次に図 6 のコンセプトについて説明する。パルスフ ォーミングにおいて，地合を良くするための分散効果 は压力パルスの大きさに依存することは良く知られて おり，筆者等の研究によれば，その大きさは (1)ブレ 一ド先端におけるワイヤ折れ角度, (2)脱水抵抗がその 主たる要素であることが判っている。従って, 通常の ワイヤよりはるかにおおきな脱水抵抗を持つフェルト 十湿紙でフォーミングシューの曲率上の原料を挟み込 んで脱水を行う本コンセプトは, 四 6 に見られる様に

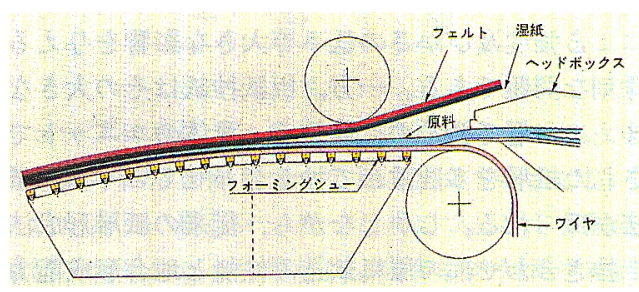

図 5 フォーミングコンセプト(1)

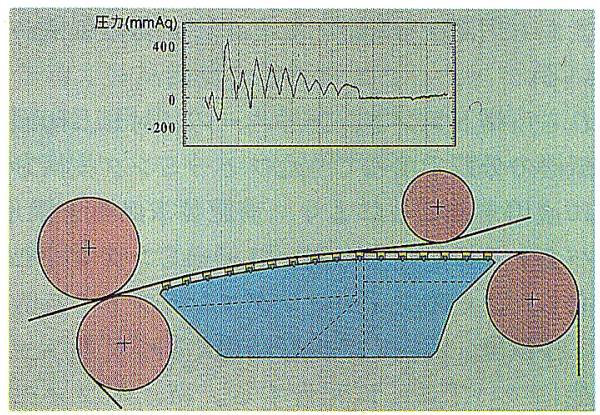

図 6 フォーミングコンセプト(2) 
低速においても大きな圧力パルスを得ることが出来， 地合改善効果が高くなる。尚, 各ユニットでの脱水は ワイヤ上に形成されたマットを通して行われるため, ブレード間隔は十分広く取り, 脱水を助けるための真 空も掛けることが出来る様配慮してある。

\section{3 全体配置形成と特徵}

本フォーマの典型的な配置形式を図 7 に示す。

上図はインバースタイプと呼んでおり，各ユニット で抄き合わされた湿紙は，最終ユニット後キャリヤフ エルトに移行, 反転されフローバックでさらに脱水さ れた後プレスパートへ送られる。従って, 紙の表面は フォーミングュニットでのワイヤ面となる。一方，下 図はストレートスルータイプであり, 湿紙は最終ユニ ットのワイヤに乗ったままプレスパートへ送られる。 従って, 表面にはインバースタイプとは逆にフェルト 面が現れる。両形式は紙種によって使い分けられる ものであるが, 何れの場合もウェットフェルトを介し て搾水するプライマリプレスを持たないので，ウェッ トフェルトマークの間題は解消されるものと思われる。

\section{3. テスト抄紙機による検証}

図 8 に示す 2 層抄テスト抄紙機を使用し, 前記フォ ーミングコンセプトの検証を行ったのでその結果につ いて報告する。

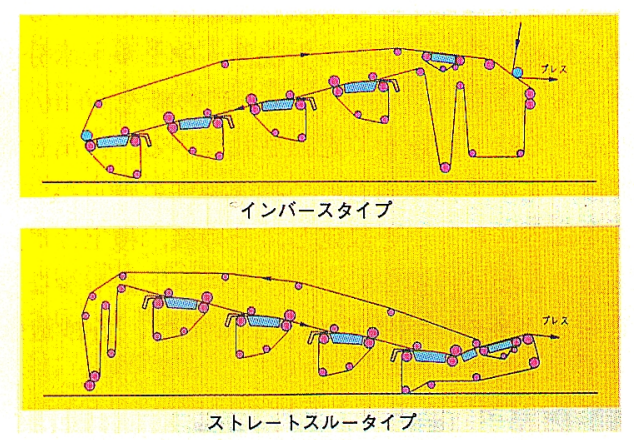

図 7 全体配置形式

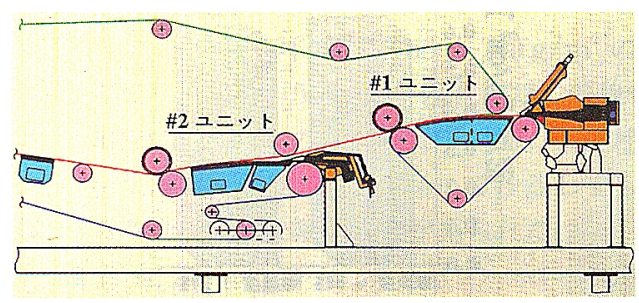

图８２層抄テスト抄紙機レイアウト

\section{1 抄造能力}

各フォーミングユニット単層能力を調べるため, 段 古紙をフリーネス $250 \mathrm{CSF}$ に吒解した原料を使用し 抄紙した結果を図 9 に示方。フェルト側への脱水抵抗 が高い 2 層目の方が1層目より若干付け量が少なくな る傾向は見られるが, 低速 (検証最低速度 $60 \mathrm{~m} /$ min.）に打いても飲み込み不良等による欠陥も見ら れず十分高い抄造能力を示している。これは, 抄き合 わせを大きな曲率半径上で行うことにより，原料飲み 込み部で原料に付与される圧力を大幅に軽減したこと， 及び真空による脱水増が相まった結果である。尚, 脱 水能力の指標である各ユニット後の湿紙濃度も 14 15\%と十分高いものが得られている。

\section{2 層間強度}

板紙の強度において最も重要視されるものの1つで ある層間強度について, 原料, 坪量, プレス条件を同 じにして単層抄紙，二層抄紙したサンプルに対しスコ ットボンド值を比較した。結果を図 10 に示す。前記 の様に，一旦，14１5\%に脱水された湿紙に抄き合わ せを行った二層抄紙サンプルであるが，その層間強度 は単層抄紙サンプルの $84 \%$ と十分高い強度が得られ ている。これは, 抄き合わせ部で二層目の原料水分に より一層目湿紙が十分再湿した後, 繊維間結合が行わ れるというウェットオンセミドライコンセプトの結果

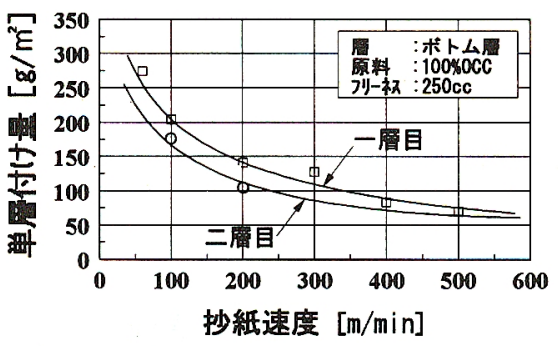

図 9 単層抄造能力

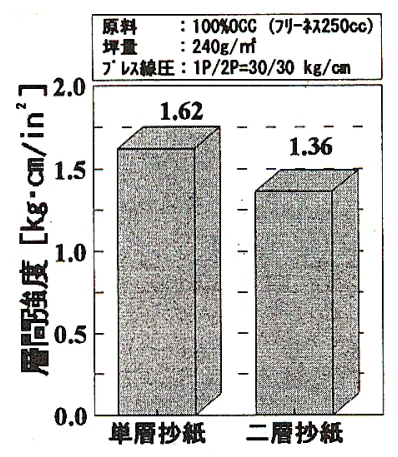

図 10 層間強度比較 
である。

\section{3 層 純 度}

白板紙, ライナ紙に要求される品質の 1 つに表層に よる中層の鿵蔽度 (Coverage) がある。鿵蔽度を左 右する因子として, 表, 表下層の地合及び各層が混ざ り合っていない度合（層純度）があるが，ここでは後 者を取り上げ, 表層白色度の低下を単層重ね合わせ紙, 二層抄き合わせ紙で比較することにより評価した。結 果を図 11 に示す。白色度 78.5 , 付け量 $50 \mathrm{~g} / \mathrm{m}^{2}$ の BKP で白色度 51.7 の新聞 DIP をカバーした抄き合 わせ紙を作製すると，表層の白色度は約 7 ポイント低 下し 71.2 となった。この低下度合は同じ BKP 原料 $50 \mathrm{~g} / \mathrm{m}^{2}$ の単層紙（純度 $100 \%$ ）を新聞 DIP の単層紙 に重ね合わせた時とほほ同じである。従って, 本フォ 一マで形成された抄き合わせ紙は層間の緎維の混ざり はなく, 各層の純度は $100 \%$ に近いものが得られてい ることが実証された。これは, 各ユニットで形成され る紙層は既に繊維の移動の起こり得ないマット濃度 （14１5\%）になってから抄き合わせが行われている こと, 脱水がワイヤを通しての一方向であるフォーミ ングコンセプトからして当然の結果である。尚, 参考 のため, 表層付け量と白色度の関係を図 12 に示す。

\section{4 禽高な紙層構造}

板紙における重要な強度に耐析, 压縮強度がある。

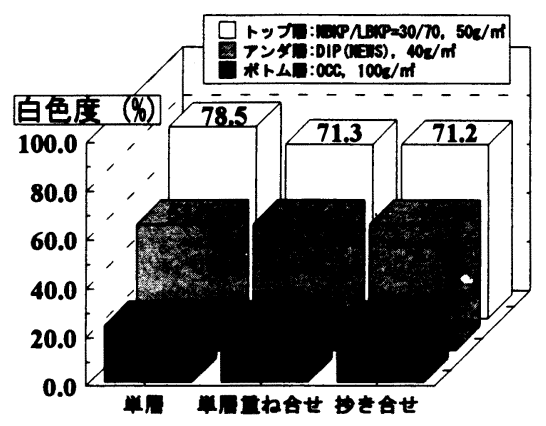

図 11 Converge 性能(1)

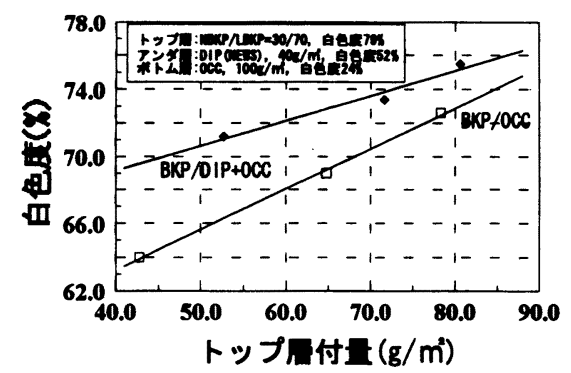

図 12 Converge 性能(2)
これらを支配する剛度は厚みの影響を大きく受けるの で，同じ坪量で厚みの大きい嵩高な紙が要求される。 紙の嵩はプレス，カレンダの影響が大きいが，ここで は紙層形成の観点から本フォーミングコンセプトによ る可能性を調查した。抄紙濃度の嵩への影響を調べる ため，原料及びプレス条件を同じにして，従来濃度 （約 $0.8 \% ） て ゙ 二$ 層抄きした紙と約 1.5 倍高い濃度 （約 1.2\%）で単層抄紙した紙の密度の比較を図 13 に 示す。抄紙濃度の高い単層抄きの紙の方が密度が低い 結果となった。本へッドボックスで採用した加減速流 路は図 4 に示す様に $1.5 \%$ という高い濃度においても 良好な分散が得られるため, 従来より濃度を高くした 抄紙が可能である。従って, 中層を従来より高い濃度 で付け量を大きく（ユニット数が減る）して抄造でき る本フォーミングコンセプトは, 嵩高な紙を造る可能 性が示唆された。

\section{4. 実機による検証}

本フォーマの 1 号機が本年 6 月, 福山製紙殿で稼働 したので，その概要について報告する。図 14 にフォ ーマレイアウト及び仕様を示す。本フォーマは図7の 下図に示すストレートスルータイプの配置であり，4 層共同一原料で最高 $700 \mathrm{~g} / \mathrm{m}^{2}$ までの板紙を生産して いる。

\section{1 運転性及び脱水能力}

本フォーマの稼働に際し, 最大の懸念事項であった アンダフェルトキャリヤ方式の湿紙搬送における「種 落ち」に対しては, フェルト洗浄, フェルト水分を最 適化することにより最高 $700 \mathrm{~g} / \mathrm{m}^{2}$ の紙を $60 \mathrm{~m} / \mathrm{min}$. で抄造する時も問題なく運転されている。抄出し時の 調整は，先ず，白水廻しにて抄速条件に合ったジェッ 卜速度に各ユニットを設定し, その後, 種上げポンプ を起動するだけの操作であり, ユニット数も少なく簡 単である。運転中の操作項目としては, 各抄造条件

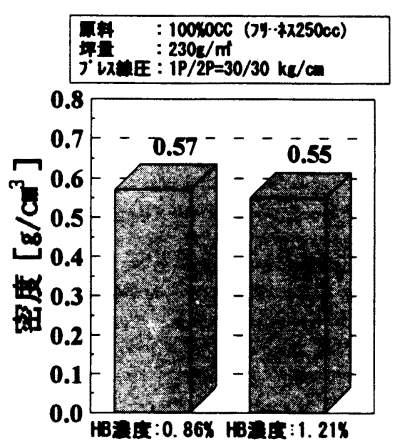

図 13 密度比較 


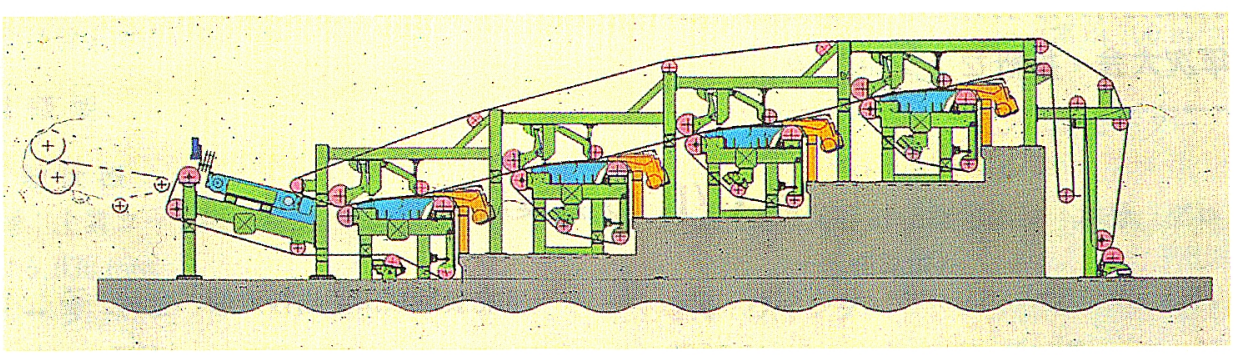

図 14 MH-Bフォーマレイアウト

(付け量，抄速）に応じて行うフォーミングシューの 真空度調整, スライスリップ微調によるプロファイル 調整がある。フォーミングシュー真空度は前半 (フラ

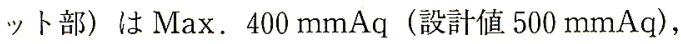

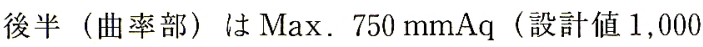
$\mathrm{mmAq})$ で運転されて扮り, 脱水能力不足から来る クーチ部での「つぶれ」等の不具合もない。フォーマ 出口の湿紙濃度は予測していた $20 \%$ 程度が得られて おり，テスト機での運転結果を合わせ試算するとフロ 一バックにより約 $5 \%$ 湿紙濃度が高吼ていること になる。

\section{2 紙 品 質}

本フォーマは，客先マシン（円網７層）をスクラッ プ\&ビルドして建設されたものである。そこで従来の 円網抄造品との対比で紙品質を評価した。

\section{(1) 強度}

抄き合わせ方法の違いによる低下が懸念されていた 層間強度は従来品より高いものが得られている。従つ て，円網において一部使用されていたスターチシャワ 一によるスターチ添加の必要性はない。

その他の強度も従来の円網抄造品上り若干の向上が 見られている。更に，本つォーマによって抄造された 紙は, 縦横比が従来の円網に比べ非常に小さく（円網 3.5 に対し 2 程度)，異方性の少ない紙となっている。 これは, 円網の場合, バット内原料とシリンダ間に働 く剪断力が強く配向度が高くなるが, $\mathrm{MH}-\mathrm{B}$ 〉ォー マは水平脱水ゾーンにジェットを乗せるため, その影 響が少ないことからして当然の結果である。

（2）地合，表面性

本フォーマは, 現在坪量範囲 $350 \sim 700 \mathrm{~g} / \mathrm{m}^{2}$ の紙 を抄造しており，薄物 $\left(500 \mathrm{~g} / \mathrm{m}^{2}\right.$ 程度まで）の地合， 表面性は非常に優れたものが得られている。又, 坪量 が大きくなり，高い濃度（約 1.5\%）で抄造しても， 従来の円網の地合より大幅な改善が見られた。

(3) 繊 維 配 向

本フォーマで抄造された紙は, 従来の円網抄造品に

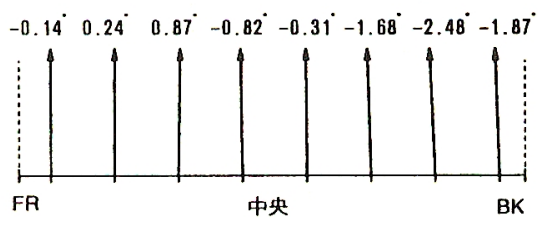

図 15 繊維配向性

比べ紙ぐせが非常に良いとの評価を受けている。そこ でその要因の 1 つである繊維配向性を調査したので図 15 に示方。本図は全巾紙（約 $3,300 \mathrm{~mm}$ ）の巾方向 8 ヶ所の配向性を示したものであり，配向角は $2.5^{\circ}$ 以 内と非常に小さく配向性が良いことがわかる。これは， へッドボックスから噴出されるジェットの直進性が良 いことを示唆している。この配向性の良さと前記異方 性の少なさが相まって，紙ぐせの良さにつながってい るものと思われる。

\section{6. 結言}

板紙市場のニーズに応える為, 従来より紙の分野で

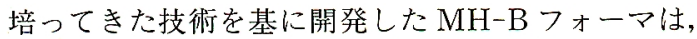
そのユニークなフォーミングコンセプトにより，板紙 に要求される紙品質を最適化出来ることが実証された。 又，そのコンパクトな設計と単層抄造能力増によるユ ニット数減は設置面積, 消費動力の面でも利点の多い 機械であると思われる。当社としては, 知識, 経験の 少ない分野であったが，これを機会に今後，本つォー マの種乃板紙への適用拡大を図る中で業界に貢献して 行く所存である。しかしながら，機械メ一カだけでは 行き届かぬ所も市り，製紙メーカ各社の御協力をお願 い致します。尚，最後になりましたが，本フォーマの 開発に際し有益な御助言をいただいた得能正照殿 （SK エンジニアリング哧）及び本フォーマの一号機 を御採用いただき，テスト機での検証から実機稼働に 至るまで多大の御協力をいただいた福山製紙殿に感謝 の意を表します。 